\title{
KULTUR PESANTREN MODERN: INTEGRASI SISTEM MADRASAH DAN PESANTREN DI PONDOK MODERN GONTOR
}

\author{
Moh. In'ami \\ STAIN Kudus \\ Jl. Conge Ngembal Rejo PO.BOX 51 Kudus \\ Telp. (+62-291) 432677 Kudus 59322 \\ E-mail: inami95@yahoo.co.id \\ HP. +62-81228273939
}

Abstract: This article describes and analyzes in]tegrity of school and boarding school cultural system. The data is collected using observation, interview and observation. In Gontor Boarding School, the students study several subjects which are combined with religious knowledge. The boarding school itself designs the learning system as a tool by giving some obligation to the students.

Abstrak: Artikel mencoba mendeskripsikan dan menganalisis integrasi sistem budaya sekolah (madrasah) dan pesantren. Pengalaman Pesantren Modern Gontor sebagai pintu masuk kajian ini. Telah maklum, bahwa pesantren merupakan lembaga spesialis tafaqquh fi al-din (memahami agama). Datadata dikumpulkan dengan observasi, wawancara, dan dokumentasi. Data yang telah terkumpul direduksi, ditampilkan, dan ditarik benang merahnya. Artikel ini menunjukkan bahwa integrasi budaya pesantren dengan madrasah didasari falsafah bahwa yang mendidik memerlukan alat. Alat mendidik adalah serangkaian tugas. Baik tugas akademik maupun tugas hidup. Kedua tugas ini diramu di Pesantren Gontor.

Kata Kunci: integrasi, Pondok Modern Gontor, tradisi pesantren, sorogan, bandongan.

\section{A. Pendahuluan}

Gagasan modernisasi Islam yang menemukan momentumnya sejak awal abad ke-20, pada lapangan pendidikan direalisasikan dengan pembentukan lembaga-lembaga pendidikan modern yang dipengaruhi, atau bahkan diadopsi dari sistem pendidikan kolonial dengan tetap bercirikan keislaman (Azra, 1998: 90). 
Usaha modernisasi pendidikan Islam di negara-negara muslim selalu menjadi pilihan untuk mengatasi tantangan terhadap dominasi sistem pendidikan modern yang diperkenalkan oleh penjajah. Pola-pola pendidikan Islam di negara-negara Timur Tengah telah mendapat tantangan untuk berubah sejak awal abad ke-19. Dalam kasus Al-Azhar misalnya, pembaharuan banyak dilakukan setelah penaklukan Bonaparte atas Mesir. Adapun pendidikan Islam di Asia Selatan telah mendapat perubahan dan pembaharuan pada pertengahan abad ke-19, khususnya yang terjadi pada kasus Aligarch (1875) (Abaza, 1994: 24).

\section{B. Fenomena Pendidikan Islam di Indonesia}

Dari beberapa kasus pembaharuan pendidikan Islam di berbagai kawasan muslim, dapat diasumsikan bahwa usaha tersebut sebagai respon terhadap ketertinggalan pendidikan Islam saat itu bila dihadapkan dengan pendidikan kolonial atau Barat, kalau tidak dapat dikatakan sebagai pengaruh dari pendidikan Barat itu sendiri. Dalam kasus di Indonesia, kalaupun ada beberapa kalangan yang kurang sependapat dengan asumsi tadi, dengan menyebutkan bahwa madrasah di Indonesia merupakan kelanjutan dari pendidikan Islam di Timur Tengah, namun madrasah di Indonesia bukanlah madrasah dalam tradisi pendidikan Islam di Timur Tengah pada abad ke11 dan 12 (Syalabi, 1987: 116), tetapi sangat dimungkinkan merupakan konsekuensi dari pengaruh intensif pembaharuan pendidikan Islam di Timur Tengah pada masa modern setelah bersentuhan dengan pendidikan Barat.

Pada awal perkembangan gagasan modernisasi pendidikan Islam ini setidak-tidaknya, menurut Azyumardi Azra, terdapat dua kecenderungan pokok dalam eksperimentasi pada pembaharuan pendidikan Islam di Indonesia. Pertama adalah adopsi sistem dan lembaga pendidikan modern secara hampir menyeluruh. Kedua adalah eksperimen yang bertitik tolak dari sistem dan kelembagaan pendidikan Islam (tradisional) di Indonesia (Azra, 1998: 36).

Eksperimen pertama tampak seperti apa yang dilakukan oleh Abdullah Ahmad dengan madrasah Adabiyah (1907). Selain mengadopsi seluruh kurikulum HIS Belanda, ditambahkan pelajaran agama 2 jam dalam sepekan (Yunus, 1995: 63) Selaras dengan itu adalah sekolah-sekolah yang didirikan oleh Muhammadiyah seperti MULO, HIS, dan selainnya. Yang membedakannya dengan sekolah-sekolah Belanda adalah dimasukkannya pendidikan agama dalam kurikulumnya. Dalam batas-batas tertentu Muhammadiyah juga bereksperimen dengan sistem dan kelembagaan madrasah modern dalam bentuk lain dengan mendirikan Madrasah Mu'allimat, dengan tetap tidak menjadikan 
sistem dan kelembagaan pendidikan Islam tradisional (surau atau pesantren) sebagai basisnya (Azra, 1998: 17).

Eksperimen kedua dilakukan dengan memodernisasi sistem dan kelembagaan pendidikan Islam indigenous dengan mengadopsi aspek-aspek tertentu dari sistem pendidikan modern, khususnya dalam kandungan kurikulum serta teknik dan metode pengajaran. Eksperimen semacam ini agaknya dilakukan pertama kali oleh Pesantren Manba'ul Ulum Surakarta (1906). Eksperimen lebih terkenal dilakukan H. Abdul Karim Amrullah yang menjadikan Surau Jembatan Besi, lembaga pendidikan Islam tradisional di Minangkabau, sebagai basis untuk pengembangan madrasah modern yang kemudian lebih dikenal sebagai Sumatera Thawalib (1916) (Daya, 1990: 47). Berbarengan dengan itu Zainuddin Labay el-Yunusi mengembangkan Madrasah Diniyah (Azra, 1998: $37)$.

Respon yang sama tetapi dalam nuansa yang berbeda terlihat dalam pembinaan kembali Pondok Gontor Lama, sehingga menjadi Pondok Modern Gontor (1926) dengan madrasah Kulliyatul Mu'allimin al-Islamiyah (KMI) pada tahun 1937. (Rahardjo, 1995: 141) Selain memasukkan pelajaran umum ke dalam kurikulumnya, siswa KMI didorong untuk menguasai secara aktif bahasa Arab dan Inggris. Kedua bahasa tersebut selain digunakan untuk berkomunikasi dalam pergaulan sehari-hari, juga digunakan sebagai bahasa pengantar dalam mengajarkan materi-materi pelajaran di kelas-kelas di samping bahasa Indonesia.

Selanjutnya, berkenaan dengan eksistensi KMI di Pondok Modern, sebenarnya bukanlah ide orisinil Gontor. Model sekolah seperti yang dimaksud pertama kali diperkenalkan di Indonesia oleh Prof. Mahmud Yunus pada tahun 1931 di Padang sepulangnya dari Mesir (Wiryosukarto, 1996: 32). Namun, ada distingsi pokok antara KMI Gontor dengan KMI Mahmud Yunus dan madrasahmadrasah di pesantren pada umumnya. KMI Mahmud Yunus termasuk dalam kategori eksperimen pertama. Sedang KMI Gontor termasuk dalam kategori eksperimen kedua yang berbasis pada pesantren. Adapun yang membedakannya dengan madrasah-madrasah di pesantren adalah, bahwa madrasah-madrasah itu terpisah dari dan sebagai tambahan sistem pesantren yang tetap mengajarkan kitab-kitab dengan metode tradisional yang khas itu. Sedangkan KMI Gontor adalah sistem madrasah modern yang mengintegrasikan dengan sistem pesantren. Keduanya menjadi bagian yang tak terpisahkan antara satu dengan lainnya.

Pengelompokan siswa seperti tersebut di atas, tidak ditemukan lagi di Pondok Modern Gontor. Semua siswa harus tinggal di asrama dan mengikuti 
pendidikan formal di KMI. Seluruh kegiatan pembelajaran siswa diadakan secara klasikal, berjenjang, terpimpin dan terorganisir serta dalam jangka waktu (Wardun, 2003: 3) Di samping itu juga unt uk menerapkan doktrin efisiensi dalam pengajaran, sistem pengajaran kitab dengan metode tarjamah yang mengartikannya dari kata perkata atau lazimnya disebut sorogan, weton atau bandongan juga telah ditinggalkan. Kitab-kitab kuning seperti Fath al-Qarīb telah digantikan dengan kitab-kitab yang telah disederhanakan dalam susunan yang lebih madrasi, sehingga lebih efektif untuk mencapai tujuan pelajaran (Nata, 2000: 205). Bahkan beberapa kitab pelajaran di KMI disusunnya sendiri.

Hal lain yang menarik dari KMI Gontor adalah keteguhannya untuk dapat bertahan dalam kurun waktu yang tidak pendek, bahkan terus berkembang. Sementara lembaga pendidikan serupa, jika tidak ditut up seperti KMI Mahmud Yunus (1946), juga mengalami perubahan status menjadi Sekolah Menengah Umum yang bercirikan khas agama Islam sebagaimana yang banyak terjadi pada Madrasah Aliyah di berbagai pesantren (1993) (Maksum, 1999: 158). Hal ini dikarenakan pendidikan di KMI Gontor dilandasi oleh ide orisinil yang dihayati dan diyakininya, dan cita-cita tertentu yang senantiasa diperjuangkan yang tersusun dalam rencana induk bagi pesantrennya (Penyusun, TT) sehingga ia tidak "latah" untuk menghadapi kurikulum yang berasal dari Departemen Agama maupun Departemen Pendidikan Nasional. Bahkan dengan kurikulum yang dirancang sendiri, KMI Gontor sangat leluasa dalam mengembangkan pendidikannya. Adapun pesantren-pesantren lainnya, pada umumnya mereka tidak merancang sendiri kurikulum kuliah madrasahnya.

Hal mendasar pada deskripsi di atas, dapat ditegaskan bahwa permasalahan yang menjadi wilayah kajian ini adalah integrasi sistem pendidikan pesantren dan madrasah di Pondok Modern Gontor dengan fokus pembahasan pada fenomena Pesantren dan Madrasah yang menjadi bagian penting dalam proses pendidikan dan pengajaran di Pondok Modern Gontor. Pertanyaannya yang diajukan adalah: Mengapa Pondok Modern Gontor mengintegrasikan sistem pendidikan pesantren dan madrasah?

\section{Sistem Pendidikan Pesantren dan Madrasah}

\section{Pondok Pesantren}

Dunia pesantren dalam berbagai variasinya merupakan pusat persemaian dan pusat dipraktikkannya ilmu-ilmu keislaman sekaligus sebagai pusat penyebarannya. Bagi Amin Abdullah, peran kelembagaan pesanten dalam meneruskan tradisi keilmuan Islam klasik sangatlah besar (Abdullah, 1995: 30), 
terlepas dari apakah lembaga pesantren merupakan karya budaya yang bersifat indigenous (asli) Indonesia ataukah model kelembagaan Islam yang diimpor dari Mesir seperti yang diisyaratkan oleh Martin van Bruinessen tidak menjadi soal.

Ilmu-ilmu yang berporos pada piramida kalam, fiqh, dan tasawuf dengan berbagai variasi aksentuasi pembidangan yang menjadi ciri khas masingmasing pesantren merupakan wilayah sekaligus media pelestarian dan pengalaman ajaran dan tradisi Islam. Jika tidak ada lembaga seperti pesantren, tentu tidak dapat dibayangkan lembaga apa yang dapat menjaga dan melestarikan tradisi keilmuan Islam yang mempunyai ciri spesifik seperti itu dan lagi mampu bertahan dalam arus perubahan sosial macam apapun.

\section{a. Pengertian Pesantren}

Terminologi pesantren mengindikasikan bahwa secara kultural pesantren (Bawani, 1993: 191) lahir dari budaya Indonesia, dengan melihat bahwa pesantren yang berasal dari bahasa Jawa, dari kata "cantrik" yang berarti seseorang yang selalu mengikuti seorang guru ke mana guru ini pergi menetap. Kemudian terma pesantren lebih populer dengan sebutan pondok pesantren. Lain halnya dengan pesantren, pondok berasal dari bahasa Arab "fundūq", yang berarti hotel, asrama, rumah, dan tempat tinggal sederhana (Hasbullah, 2002: 64).

Menurut Manfred Ziemek, kata pondok berasal dari kata fundūq (bahasa Arab) yang berarti ruang tidur atau wisma sederhana, karena pondok memang merupakan tempat penampungan sederhana bagi para pelajar yang jauh dari tempat asalnya. Sedangkan kata pesantren berasal dari kata santri yang mendapat imbuhan pe-pada awal kata dan akhiran -an yang berarti menunjukkan tempat, yang artinya adalah 'tempat para santri'. Terkadang juga dianggap sebagai gabungan kata sant (manusia baik) dengan suku kata tra (suka menolong), sehingga pesantren dapat dimaknai sebagai 'tempat pendidikan manusia baik-baik' (Wahjoetomo, 1997: 70).

K.H. Imam Zarkasyi menjelaskan bahwa pesantren berasal dari dua kata yang membentuk satu pengertian yang sama. Pondok berarti tempat untuk menumpang sementara, pesantren berarti tempat para santri, sedangkan santri berarti pelajar yang menunt ut ilmu agama Islam. Tidak ada perbedaan yang berarti antara sebutan pondok atau pesantren, karena keduanya merujuk kepada satu pengertian yang sama (Tim Penyusun, 1996: 54).

Menurut Azizy (2002: vii), pesantren merupakan sistem pendidikan tertua khas Indonesia. Ia merupakan sumber inspirasi yang tidak pernah kering bagi 
para pecinta ilmu dan peneliti yang berupaya mengurai anatominya dari berbagai dimensi.

Dalam lingkungan fisik yang demikian itu, diciptakan semacam cara kehidupan yang memiliki sifat dan ciri tersendiri, dimulai dengan jadwal kegiatan yang memang menyimpang dari pengertian rutin kegiatan masyarakat sekitarnya. Pertama-tama, kegiatan di pesantren berputar pada pembagian periode berdasarkan waktu shalat lima waktu. Dengan sendirinya, pengertian waktu pagi, siang dan sore di pesantren akan menjadi berlainan dengan pengertian di luarnya. Dalam rangka inilah, umpamanya, sering dijumpai para santri yang menanak nasi di tengah malam buta atau yang mencuci pakaiannya menjelang terbenamnya matahari. Dimensi waktu yang unik ini tercipta karena kegiatan pokok pesantren dipusatkan pada pemberian pengajian buku-buku teks, yang dikenal dengan istilah kitab kuning, pada tiap-tiap habis menjalani sembahyang wajib.

Pondok pesantren tumbuh sebagai perwujudan dari strategi umat Islam untuk mempertahankan eksistensinya terhadap pengaruh penjajahan Barat dan atau akibat surau atau langgar/masjid tempat diselenggarakannya pendidikan agama yang tidak lagi dapat menampung jumlah anak-anak yang ingin mengaji. Di samping itu, juga didorong oleh keinginan untuk lebih mengintensifkan pendidikan agama pada anak-anak. Maka kiai atau ustadz dengan bantuan masyarakat memperluas bangunan di sekitar surau, langgar atau masjid untuk tempat mengaji dan sekaligus sebagai asrama bagi anak-anak. Dengan demikian anak-anak dapat menetap tinggal bersama Kiai dan ustadz di tempat tersebut, yang kemudian dikenal dengan sebutan pondok pesantren (Zuhairini, 1997: 212) Dan dari sinilah aktivitas pendidikan keagamaan itu dilakukan dengan penuh kesadaran.

Sesuai dengan namanya, maka pondok berarti tempat menginap (asrama), dan pesantren berarti tempat santri mengaji ilmu agama Islam. Jadi, pondok pesantren adalah tempat murid-murid (yang kemudian disebut santri) mengaji ilmu-ilmu agama Islam dan sekaligus diasramakan di tempat tersebut.

Santri-santri berasal dari berbagai macam latar belakang yang berbeda, namun mereka tinggal di pondok pesantren tersebut sebagai satu keluarga di bawah pimpinan kiainya. Mereka belajar hidup mandiri, mencuci sendiri dan mengurus hal ihwalnya sendiri. Bahan-bahan keperluan hidup seperti beras dan sebagainya mereka bawa dari kampung sendiri.

Di pondok pesantren, para santri, besar dan kecil duduk melingkar (halaqah) mengelilingi kiai. Mereka menerima pelajaran yang sama. Tidak ada 
perencanaan dalam hal kurikulum tertentu berdasar pertimbangan umur, lama belajar, dan atau tingkat pengetahuan. Bagi para santri diperbolehkan untuk memilih bidang pengetahuan apa yang akan dipelajari dan pada tingkat pelajaran mana mereka ingin memulai.

Seorang santri yang baru masuk di pondok pesantren, tidak secara langsung belajar pada kiai, kecuali apabila yang bersangkutan telah memiliki kemampuan. Biasanya santri baru belajar lebih dahulu pada asisten kiai tersebut, yaitu seorang santri senior yang telah jauh kajiannya, yang kemudian disebut ustadz yang membantu atau badal. Bila santri telah mampu membaca dan dapat memahami ala kadarnya kitab, barulah dia menyertai kelompok yang langsung mengaji pada kiai pesantren tersebut (Noer, 1982: 15).

\section{b. Sejarah Munculnya Pesantren}

Referensi yang menjelaskan tentang kapan pondok pesantren pertama berdiri dan bagaimana perkembangannya pada zaman permulaan tidak banyak ditemukan. Meski demikian terma pondok pesantren, kiai, dan santri tidak lagi diperselisihkan seiring dengan minat dan motivasi yang tinggi berbagai pihak dalam memahami urgensi lembaga pendidikan Islam yang klasik tersebut.

Perjalanan panjang pendidikan pesantren di Indonesia dapat ditelusuri melalui bentuk-bentuk pendidikan yang diselenggarakan di langgar, masjid dan rumah-rumah penduduk dan guru ngaji yang bersangkutan. Perkembangan selanjutnya, lembaga-lembaga pendidikan yang pada mulanya tidak lebih sekedar berupa kumpulan anak-anak yang belajar pengetahuan agama pada tingkat dasar seperti membaca al-Qur'ān, shalat dan semacamnya ini berubah bentuk dan isinya. Lembaga-lembaga tersebut telah menjelma menjadi madrasah diniyah, kemudian berkembang menjadi pondok pesantren.

Proses berdirinya sebuah pesantren biasanya diprakarsai sekelompok santri yang mengadakan perhitungan dan memperkirakan kemungkinan kehidupan bersama para ustadz atau kiainya. Tidak jarang pesantren juga berdiri atas inisiatif kiai untuk mengamalkan ilmunya sehingga perlu membangun sebuah lembaga pendidikan. Atas dasar itu, maka berdirilah sebuah pondok, tempat yang tepat untuk kehidupan bersama bagi para santri dengan para ustadz dan kiainya.

Biasanya pesantren terdiri dari sekumpulan pondok (surau kecil-kecil) yang terletak dekat sebuah masjid. Pondok-pondok itu didirikan dengan uang wakaf atau sedekah yang diberikan oleh orang-orang yang mampu, bahkan ada juga dengan kemauan dan ongkos sendiri dari santri-santri yang datang belajar kesana. Murid-murid tinggal di pondok pesantren bersama-sama sebagai satu 
keluarga di bawah pimpinan kiai. Mereka belajar hidup sendiri, memasak sendiri, mencuci sendiri, dan mengurus hal ihwalnya sendiri (Yunus, 1995: 231)

Sebelum masa kemerdekaan pesantren telah menjadi sistem pendidikan Nusantara. Hampir di seluruh pelosok Nusantara, khususnya di pusat-pusat kerajaan Islam telah terdapat lembaga pendidikan yang kurang lebih serupa walaupun menggunakan nama yang berbeda-beda, seperti Meunasah di Aceh, Surau di Minangkabau dan Pesantren di Jawa (Hakim, 2001: 3).

Dalam masa Orde Baru telah dilancarkan lima komponen pendidikan oleh dunia pesantren, yaitu: Pengajaran dan pendidikan agama; Ketrampilan sesuai dengan kemampuan dan kebutuhan masyarakat sekitarnya; Kepramukaan, di mana pendidikan dan disiplin agama dapat dilakukan dengan perantaraan kegiatan pramuka; Kesehatan dan olah raga. Hal ini perlu ditingkatkan di pondok pesantren, karena ternyata masih banyak pondok pesantren yang kurang mengambil perhatian terhadap kesehatan dan olah raga; dan kesenian yang bernafaskan Islam (Ali, 1987: 21).

Sebagai lembaga pendidikan indegenous yang tertua, pesantren memiliki kontribusi yang sangat signifikan dalam menciptakan generasi akhlak karimah. Sistem pendidikan tradisional pesantren terbukti memiliki tingkat resistensi dan adaptability yang tinggi. Pesantren tetap survive dan mampu beradaptasi dengan modernitas pendidikan. Bahkan pada saat pendidikan yang cenderung sekuler dinilai gagal, pesantren ditunjuk sebagai lembaga pendidikan alternatif (Mukti, 1998).

Dalam kehidupan masyarakat yang beragama, pesantren diharapkan memberikan kontribusi yang nyata. Dan pesantren telah menunjukkan eksistensinya melalui tiga jenis peranan, yaitu peranan dasar, peranan saling menunjang (complement) dan peranan pelengkap. Pada peranan pelengkap, pesantren mengerjakan bagian yang sudah dirintis oleh kalangan pesantren lain yang berhubungan dengan program yang direncanakan oleh sendiri. Sedangkan para peranan saling menunjang, pihak lain dengan terbuka diharapkan mempersilakan pesantren menentukan sendiri wilayah garapan yang diinginkan, dalam sebuah kerangka yang lebih luas. Sedangkan peranan dasar pesantren meliputi hal-hal sebagai berikut: Pendidikan formal, nonformal, dan informal di bidang keagamaan dan kemasyarakatan; Pelayanan masyarakat, melalui kegiatan, konsultasi, bimbingan maupun pengembangan masyarakat; Dakwah melalui pengajian khusus dan umum; Pengembangan pemikiran keagamaan dan kemasyarakatan melalui majlis ta' ${ }_{i j}$, kajian dan penyebaran informasi; dan pembentukan jaringan komunikasi eksternal yang bersifat antar kelompok dan golongan (Hasan, 1988: 113). 
Karena menjadi lembaga yang mapan, pesantren pun berinteraksi dengan realitas kehidupan. Masyarakat pada garis besarnya turut merespon munculnya perbedaan nilai kehidupan modern. Nilai dan norma-norma pesamtren harus berinteraksi dengan timbulnya perbenturan-perbenturan melalui kemajuan media komunikasi. Hanya terdapat dua pilihan bagi pesantren: pertama, memperketat tradisi dan mengisolasi diri dari luar atau secara aktif mau tak mau berinteraksi bersama dengan nilai-nilai baru dan memberikan suatu kesempatan kepada masyarakat Islam untuk mempergunakan ajaran Islam dalam menghadapi kenyataan, agar mereka membuat keputusan mereka sendiri; pilihan yang kedua, sebaiknya pesantren dapat bertindak hanya sebagai fasilitator yang memungkinkan masyarakat Islam membuat keputusan mereka sendiri (Wirosardjono, 1988: 82).

Pada masa sekarang, apresiasi masyarakat terhadap pesantren cukup tinggi, dan kesadaran untuk mengantarkan anak-anak ke lembaga pendidikan pesantren mulai tumbuh di tengah persaingan lembaga pendidikan yang memberikan fasilitas dan pelayanan yang lebih, dan tent unya dengan biaya yang tinggi.

\section{Madrasah}

\section{a. Pengertian Madrasah}

Madrasah berasal dari bahasa Arab yang berarti tempat belajar. (Anis, 1972: 280). Sinonim kata madrasah dalam bahasa Indonesia adalah sekolah, yang lebih dikhususkan lagi dengan sekolah agama Islam. Dalam Shorter Encyclopedia of Islam, madrasah diartikan sebagai "name of an institution where the Islamic science are studied", nama dari suatu lembaga di mana ilmuilmu keislaman dipelajari" (Gibb, 1961: 300). Dalam arti tempat belajar, madrasah memang berasal dari dunia Islam, sebagai tempat mengajarkan dan mempelajari ajaran-ajaran Islam, ilmu pengetahuan dan keahlian lainnya yang berkembang pada zamannya.

Makdisi (1970: 257) berpendapat bahwa terjemahan kata madrasah dapat disimpulkan dengan tiga perbedaan mendasar, yaitu (i) kata universitas, dalam pengertiannya yang paling awal, merujuk pada komunitas atau sekelompok sarjana dan mahasiswa, (ii) merujuk pada sebuah bangunan tempat kegiatan pendidikan setelah pendidikan dasar (pendidikan tinggi) berlangsung, (iii) izin mengajar (ijazah tadris, licentia docendi) pada madrasah diberikan oleh syaikh secara personal tanpa kaitan apa-apa dengan pemerintahan.

Pada kenyataannya kata madrasah yang secara harfiyah identik dengan sekolah agama itu -mau tidak mau-diakui telah mengalami perubahan, meski 
tidak melepaskan diri dari makna asal sesuai dengan ikatan budayanya, yakni kultur Islam.

\section{b. Sejarah Munculnya Madrasah}

Madrasah sebagai satu sistem pendidikan Islam dengan sistem kelas dan mengajarkan sekaligus ilmu-ilmu keagamaan dan nonkeagamaan sudah tampak sejak awal abad ke-20. Meskipun sebagian di antara lembaga-lembaga pendidikan itu menggunakan istilah school (sekolah), tetapi dilihat dari sistem pendidikannya yang terpadu, lembaga pendidikan seperti itu biasa dikategorikan dalam bentuk madrasah (Maksum, 1999: 97).

Hubungan pertumbuhan dan perkembangan antara madrasah di Indonesia dengan madrasah di Timur Tengah lebih cenderung pada hubungan yang bersifat kurikuler, khususnya kurikulum pendidikan agamanya, karena secara kelembagaan pertumbuhan dan perkembangan madrasah di Indonesia pada masa awal tidak terlepas dari kelanjutan dan penyempurnaan dari model-model pendidikan Islam tradisional, seperti meunasah, langgar, masjid atau pesantren. Ketika terjadi proses perubahan isi pembelajaran di dalam format pembelajarannya, persentuhan global dengan pusat Islam di Harāmayn memungkinkan para pelaku pendidikan Islam melihat sistem pembelajaran yang lebih terprogram. Pola pembelajaran pelajaran-pelajaran Islam yang dikelola dengan sistem madrasi tumbuh dan berkembang.

Kehadiran madrasah sebagai lembaga pendidikan Islam setidak-tidaknya mempunyai empat latar belakang: Sebagai manifestasi dan realisasi pembaharuan sistem pendidikan Islam; Usaha penyempurnaan terhadap sistem pesantren ke arah suatu sistem pendidikan yang lebih memungkinkan lulusannya untuk memperoleh pendidikan kesempatan yang sama dengan sekolah umum, misalnya masalah kesamaan dalam kesempatan kerja dan perolehan ijazah; Adanya sikap mental pada sementara golongan umat Islam, khususnya santri yang terpukau pada Barat sebagai sistem pendidikan mereka; dan sebagai upaya untuk menjembatani antara sistem pendidikan tradisional yang dilakukan oleh pesantren dan sistem pendidikan modern dari hasil akulturasi (Muhamin, 1993: 305).

Madrasah dalam wacana kehidupan manusia Indonesia merupakan fenomena budaya yang telah berusia satu abad lebih. Bahkan bukan satu hal yang berlebihan, madrasah telah menjadi salah satu wujud entitas budaya Indonesia yang relatif intensif. Indikasinya adalah kenyataan bahwa wujud entitas budaya itu telah diakui dan diterima kehadirannya. Secara berangsur namun pasti madrasah telah memasuki arus utama pembangunan bangsa menjelang akhir abad ke-20. 


\section{Integrasi Sistem Pendidikan Pesantren dan Madrasah Di Pondok Modern Gontor}

\section{Konstruksi Pendidikan di Pondok Modern Gontor}

Sebagai lembaga pendidikan Islam yang masih survive di era global, pesantren masih menyimpan banyak hal menarik yang dapat dikaji dan dicermati. Keunikan pesantren merupakan ciri khas dari pendidikan Islam di Indonesia.

Pengelolaan pendidikan di Pondok Modern Gontor dengan sistem madrasi ini menggunakan cara pembelajaran secara klasikal. Hal ini berbeda dengan cara yang berkembang di pondok pesantren yang telah baku, yakni bersifat individual seperti yang terdapat pada sistem sorogan dan wetonan. Pengelolaan sistem madrasi berimplikasi terhadap adanya pengelompokan pelajaranpelajaran tentang pengetahuan Islam yang penyampaiannya diberikan secara bertingkat-tingkat. Pengelompokan tersebut sekaligus memperhit ungkan rentang waktu yang dibutuhkan. Sistem madrasi ini mengorganisasi kegiatan kependidikan dengan sistem kelas-kelas berjenjang dengan waktu yang diperlukan untuk menyelesaikan pelajaran yang sudah dipolakan.

Pondok Modern Gontor sebagai lembaga pendidikan Islam konsisten sejak awal berdirinya hingga kini dalam menggodok para calon pemimpin masa depan yang intelek dan tahu agama. Sebagai pesantren tempat para santri menunt ut ilmu Pondok Modern Gontor sering disebut sebagai 'kawah candradimuka', sebuah terma yang identik dengan tempat penyiapan dan pembekalan keilmuan.

Pondok Modern Gontor konsisten dalam berjuang di bidang pendidikan. Hal ini dapat dilihat dalam proses pendidikan dan pengajaran di pesantren dengan memberikan peluang yang luas bagi anak didiknya untuk berkembang dan maju dalam bidang keilmuan yang diminati. Bukan hanya itu pengembangan sumber daya manusia menjadi prioritas dalam program peningkatan kualitas guru dan murid di Pondok Modern Gontor.

Bentuk total education meliputi segi keimanan, keilmuan sampai pembentukan karakteristik, di mana santri tidak hanya mendapat transformasi keilmuan an sich melainkan juga pendidikan keterampilan dan mental. Dan Pondok Modern Gontor sudah memiliki metode dan tools (perangkat) untuk membentuk santri unggul, sehingga para alumninya mampu untuk 'hidup' di segala bidang, situasi dan kondisi.

Perbedaan antara pola pendidikan Pondok Modern Gontor dengan lainnya adalah bahwa di Pondok Modern Gontor, santri tinggal dalam lingkungan belajar yang kondusif, salah sat unya karena Pondok Modern Gontor memakai 
sistem boarding school, di mana santri berada dalam pengawasan guru 'dua puluh empat jam', sehingga kegiatan santri selalu terkontrol dan lebih banyak waktunya bersama guru. Perbedaan lain, terdapatnya life skill yang terangkum dalam aktivitas keseharian santri, mulai disiplin, penugasan dan lain sebagainya.

\section{Sistem Pendidikan Pesantren dan Madrasah di Pondok Modern Gontor}

Pesantren merupakan lembaga pendidikan Islam Indonesia pribumi, tempat umat Islam belajar dan untuk mengaplikasikan ajaran Islam dalam kehidupan sehari-harinya. Komunitas pesantren biasanya terdiri dari tiga kelompok, yaitu kiai, ustadz dan santri. Sesuai dengan peranannya dalam pembangunan masyarakat, pesantren secara terus menerus diharapkan dapat berkembang dan beradaptasi dengan hal-hal yang berkenaan dengan peningkatan sumber daya manusia dan sumber daya alam.

Dewasa ini pola pendidikan di pesantren mengalami perubahan, yang disebabkan terdapatnya dorongan keinginan yang sangat kuat pada pesantren untuk menerapkan sistem sekolah pada pendidikan di pesantren. Sistem sekolah di pesantren itu segera berkembang dengan pesat, sehingga akhir-akhir ini tinggal sedikit sekali pesantren yang tidak menggunakan sistem sekolah. Dengan menyebut madrasah, sistem sekolah di pesantren itu berusaha untuk menggabungkan pelajaran pengetahuan nonagama dalam kurikulumnya. Akan tetapi, keseragaman kurikulum tetap belum dapat diterapkan di antara mayoritas madrasah hingga saat ini. Yang berhasil hanyalah di beberapa pesantren (Wahid, 2001: 80).

Pondok Modern Gontor sebagai lembaga pendidikan Islam tentunya mempunyai suatu sistem pendidikan yang akan menentukan masa depannya, mampu menjawab tantangan zaman. Hal ini bergantung pada orientasi nilai yang dikandungnya dan ketetapan proses pengelolanya. Sistem pendidikan inilah dikatakan mampu melayani tantangan zamannya apabila ia mampu merespons kebutuhan anak didik, kemajuan ilmu dan teknologi, dan kebutuhan pembangunan nasional, dalam struktur relevansi cita-cita kehidupan sesuai dengan pandangan hidup bangsa dan ajaran agama Islam.

Sistem pendidikan yang dikembangkan di Pondok Modern Gontor memberikan kesempatan anak didik untuk mengembangkan kemampuan life skills sesuai dengan kecenderungannya sehingga mereka dapat mengaplikasikan keilmuan dan mengaktualisasikan diri dalam komunitas sosial kelak sekembalinya dari pesantren. 
Sistem pendidikan di Pondok Modern Gontor juga memberikan motivasi logis transendental berupa pedoman moral sesuai dengan keyakinan dan tantangan zaman, sehingga anak didik mampu hidup hormat dan disegani dalam tata pergaulan bersama di tengah-tengah masyarakat. Lebih dari itu, santri mampu mengembangkan ketrampilan atau keahlian budi pekerti luhur sesuai agama, kepercayaan dan kultur Islam, yang diharapkan akan dapat membawa anak didik mampu hadir di tengah-tengah kehidupan masyarakat dengan mendatangkan manfaat, rasa aman, dan kepercayaan, serta harapan bagi masyarakatnya untuk memajukan kehidupan bersama lahir-batin.

\section{Analisis Integrasi Sistem Pendidikan Pesantren dan Madrasah di Pondok Modern Gontor}

K.H. Imam Zarkasyi mengintegrasikan dua sistem (sistem madrasah dan sistem pesantren) secara total, menyeluruh dan konsekuen. Gambaran prinsip integrasi tersebut dapat dipahami secara eksplisit dalam penjelasannya, "Semua yang ada di pondok ini sengaja diciptakan untuk pendidikan". Artinya, semua aktivitas di Pondok Modern Gontor yang bersistem madrasah dan berjiwa pesantren ini saling terkait dan saling mendukung. Di samping itu pendidikan dan pengajaran di Pondok Modern Gontor diselenggarakan menurut sistem sekolah yang modern dengan mempergunakan metode modern dan senantiasa memperhatikan perkembangan dalam sistem pendidikan modern.

Pondok Modern Gontor mengintegrasikan dua sistem (sistem pesantren dan sistem sekolah) secara total, menyeluruh dan konsekuen. Semua kegiatan di Pondok Modern Gontor yang bersistem madrasah dan berjiwa pesantren ini saling terkait dan saling mendukung. (1996: 67)

\section{a. Anatomi Pesantren dan Madrasah}

Berbicara anatomi pesantren dan madrasah dalam lembaga pendidikan Pondok Modern Gontor diperlukan batasan-batasan yang jelas untuk memisahkan antara wilayah-wilayah yang masuk dalam kategori pesantren dan aspek-aspek menjadi bagian dalam katagori madrasah.

Meski batasan-batasan itu dibutuhkan, namun bagi Pondok Modern Gontor prioritas dalam pendidikannya justru terletak pada sistem yang dipakai dan model pembelajaran yang diterapkan.

Dalam wawancara penulis dengan Ustadz Ali Syarkawi, Lc., Direktur KMI Pondok Modern Gontor menyatakan:

"Kita harus punya alat untuk mendidik. Alat itu berupa tugas-tugas yang sangat banyak. Kita di sini mendidik anak dengan tugas-tugas. Materi pendidikannya ada olah raga, kesenian, al-a 'māl al-tațawwu'iyah seperti jaga 
malam, ngepel, ngecor, membersihkan kamar. Ada pendidikan berkurban, semua ini adalah perangkat lunak (soft ware) pendidikan. Sementara hard ware-nya, ada lapangan, ada sarana perpustakaan."

Bersamaan dengan berdirinya KMI sebagai suatu sistem madrasah, K.H. Imam Zarkasyi memberlakukan sistem pondok atau asrama sebagaimana pondok pesantren lainnya. Siswa KMI diharuskan tinggal di dalam pondok/ asrama seperti layaknya santri di berbagai pondok pesantren lainnya. Di dalam kelas mereka adalah siswa dan di luar kelas mereka adalah santri yang mendapat pendidikan, bimbingan, dan pengasuhan dari kiai. K.H. Imam Zarkasyi berperan sebagai Direktur madrasah (KMI) sekaligus figur kiai, sedangkan K.H. Ahmad Sahal sebagai figur kiai dan juga pengasuh. Meskipun sistem pendidikan di pondok pesantren diperbaharui dengan menerapkan prinsip-prinsip pendidikan modern, nilai dan jiwa pesantren lama tetap dipertahankan (1996: 54).

Apa yang dilakukan K.H. Imam Zarkasyi sebenarnya adalah mengikuti asas “al-Muhāâụah 'alā al-qadim al-șāliḥ wa al-akhdzu bi al-jadid al-aṣlaḥ”, dalam arti bahwa dia tetap mengajarkan kitab-kitab klasik di pesantren, tetapi dia melakukan pembaharuan dalam metode pengajarannya. Para santri di Pondok Modern Gontor lebih dahulu dibekali seperangkat ilmu dasar keislaman dan bahasa. Setelah bekal dasar tersebut dianggap cukup, barulah pada kelas akhir mereka diajak membedah kitab-kitab klasik tersebut di bawah bimbingan dan pengawasan kiai dibantu santri-santri senior. Metode ini kemudian dikenal dengan fath al-kutub.

\section{b. Model Gontor: Pendidikan Integrated}

Pendidikan Islam sebagai lembaga alternatif diharapkan mampu menyiapkan kualitas masyarakat yang bercirikan semangat keterbukaan, egaliter, kosmopolit, demokratis, dan berwawasan luas, baik aspek menyangkut aspek spiritual, maupun ilmu-ilmu modern.

Betapa dalam memodernisasi pendidikan Islam pada masa sekarang merupakan hal yang menarik untuk menemukan format pendidikan ideal sebagai sistem pendidikan alternatif bangsa Indonesia masa depan.

Usaha-usaha ke arah modernisasi pendidikan Islam pada awal abad ke-20, tampaknya masih relatif terbatas. Usaha-usaha pembaharuan dalam dunia pendidikan ini terilhami oleh wacana modernisasi yang terjadi di berbagai belahan dunia Islam lainnya. Maka di Indonesia misalnya telah tampil K.H. Ahmad Dahlan dengan mendirikan organisasi Muhammadiyah. Namun, pembaharuan yang diupayakan justru mengabaikan khazanah keislaman klasik yang menjadi elemen pertama dan penting (Yasmadi, 2002: 113). 
Nilai-nilai yang mendasari pesantren, menurut Mastuhu, dapat digolongkan menjadi dua kelompok: (a) Nilai-nilai agama yang memiliki kebenaran mutlak, yang dalam hal ini bercorak fikih-sufistik, dan berorientasi kepada kehidupan ukhrawi, dan (b) Nilai-nilai agama yang memiliki kebenaran relatif, bercorak empiris dan pragmatis untuk memecahkan berbagai masalah kehidupan sehari-hari menurut hukum agama (Mastuhu, 1994: 58).

Internalisasi nilai pendidikan pondok pesantren di Pondok Modern Gontor dapat dilihat dari keseluruhan kehidupan pondok pesantren sebagai satu kesatuan sistem kehidupan pesantren atau budaya yang berjalan 24 jam terus menerus dari tahun ke tahun, bersamaan dengan adanya unsur materiil maupun immaterial yang memformulasikan sistem pendidikan pesantren yang mencetak sekaligus membentuk perilaku santri, pola pikir dan sikap hidup serta filsafat hidupnya, dan di dalam kehidupan pesantren itulah terkandung nilai-nilai kehidupan yang luhur dan yang dicita-citakan.

K.H. Imam Zarkasyi melihat pesantren dari isinya, yang mana hal ini berbeda dengan pandangan Snouck Hurgronje, seorang orientalis yang hanya melihat pesantren dari bentuk lahiriahnya. Misalnya, bentuk rumah pondokan, cara berpakaian, peralatan yang digunakan, tata letak bangunan dan tradisitradisinya yang statis. K.H. Imam Zarkasyi menyimpulkan bahwa di dalam kehidupan pondok pesantren sekurang-kurangnya terdapat dan diusahakan tertanam lima jiwa pesantren yang kemudian dikenal dengan Panca Jiwa, yaitu: keikhlasan, kesederhanaan, kemandirian, ukhuwah islamiyah, dan kebebasan.

Sementara model madrasah yang ada di Pondok Modern Gontor adalah Kulliyat al-Mu'allimin al-Islamiyah (KMI), sebuah madrasah yang telah mengalami sentuhan pembaharuan, sebagaimana di Sumatera Barat saat itu sedang berlangsung proses pembaharuan pendidikan madrasah dengan Mahmud Yunus sebagai tokohnya.

KMI sebagai suatu sistem madrasah dikembangkan ke arah tujuan pokok pendidikan pesantren, yaitu tafaqquh fi al-din, guna mencetak ulama dan tokoh masyarakat dengan menerapkan sistem belajar yang efektif dan efisien.

Memperhatikan ide dan konsep KMI yang datang dari K.H. Imam Zarkasyi, maka disepakati bahwa yang akan memimpin atau menjadi Direkturnya adalah K.H. Imam Zarkasyi.

Dengan bermulanya sistem KMI, maka Sullamul Muta'allimin dengan segala kegiatannya dibekukan, dan siswa Sullamul Muta'allimin kemudian dialihkan menjadi siswa KMI. 


\section{a. Kurikulum KMI}

Kurikulum yang diterapkan di Pondok Modern Gontor pada awal perintisannya adalah kurikulum Normal Islam yang didirikan Mahmud Yunus. K.H. Imam Zarkasyi melakukan hal demikian itu berdasarkan pengakuan dari gurunya, Mahmud Yunus, bahwa ia dianggap mampu mendirikan dan mengajar sekolah serupa atau sederajat dengan Normal Islam atau KMI.

Kurikulum KMI Pondok Modern Gontor kemudian didesain secara seimbang antara materi-materi yang terdapat di pesantren dan madrasah, tidak sepenuhnya sama dengan Normal Islam. Materi pelajaran agama, misalnya terdiri atas 'Aqāid, al-Qur'ān dan Tajwìd, Tafsìr, Hadits dan Musțalạ̣ al-Hadits, Fiqh dan Ușūl Fiqh, Perbandingan Agama, Sejarah Kebudayaan Islam, dan lainnya. Adapun materi pelajaran umum terdiri atas Ilmu Jiwa Pendidikan (Psikologi), Asas-Asas Didaktik-Metodik, Sejarah Pendidikan, Ilmu Sosial, Biologi, IPA, Tata Negara, Berhitung dan lainnya. Selain itu materi pelajaran bahasa (Bahasa Arab dan Inggris) dipandang sebagai kunci pokok ilmu pengetahuan.

Meskipun materi pelajaran agama di KMI sama dengan materi pelajaran di pesantren-pesantren lama, tetapi kitab-kitab yang dipakai tidak seluruhnya sama. Kitab-kitab itu telah disederhanakan dalam susunan yang lebih "madrasi", sehingga lebih efektif untuk mencapai tujuan pelajaran. Beberapa kitab pelajaran di KMI bahkan disusun sendiri oleh K.H. Imam Zarkasyi, seperti pelajaran Bahasa Arab, Balāghah, 'Ilmu Mantiq, Aqīdah, Fiqh, dan Tajwìd.

Di Pondok Modern Gontor, kurikulum bukanlah sekedar susunan mata pelajaran di dalam kelas, tetapi merupakan seluruh program kependidikan. Ini berarti bahwa tujuan pelajaran di KMI bukanlah tujuan yang berdiri sendiri, melainkan dipersatukan secara integral dengan tujuan pendidikan pesantren secara keseluruhan. Sebagai sebuah pesantren, tujuan pendidikan Pondok Modern Gontor tidak berbeda dengan tujuan pesantren pada umumnya, yaitu mencetak ulama.

Dalam bidang kurikulum, KMI Pondok Modern Gontor tidak dapat dipisahkan dari pemahaman K.H. Imam Zarkasyi terhadap konsep ilmu; bahwa Islam tidak memisahkan pengetahuan agama dan pengetahuan umum. Maka dalam menggambarkan porsi materi pelajaran dalam kurikulum KMI yang diterapkannya dengan menyebut $100 \%$ agama dan $100 \%$ umum. Hal ini berarti bahwa ilmu pengetahuan umum itu sebenarnya adalah bagian dari ilmu pengetahuan agama, dan sama pentingnya (1996: 51).

Perlunya keseimbangan antara ilmu pengetahuan umum dan ilmu pengetahuan agama dalam sebuah lembaga pendidikan Islam yang bermutu dan 
berwawasan ke depan, inilah yang mendorong K.H. Imam Zarkasyi unt uk mengintegrasikan sistem madrasah dan sistem pesantren.

\section{b. Metode Pengajaran}

Metode pengajaran yang diterapkan di Pondok Modern Gontor menggunakan sistem klasikal, sebagaimana dapat dilihat di sekolah-sekolah umum atau madrasah-madrasah pada saat itu. Meski lembaganya bernama pesantren, K.H. Imam Zarkasyi tidak lagi menggunakan sistem metode pengajaran sorogan ala pesantren tradisional pada umumnya.

Dapat diilustrasikan bahwa alat bantu kapur dan papan tulis digunakan dalam pengajaran. Setiap enam bulan sekali diadakan evaluasi hasil belajar. Masa belajarnya berlangsung 5-6 tahun. Para santri belajar di dalam kelas dengan mengenakan celana panjang dari jam 07.00 pagi sampai dengan 13.00 siang. Guru mengajar dengan menggunakan celana dan berdasi. Inilah di antara awal mula anggapan orang sebagai pondok yang berciri modern.

Dalam sistem madrasah ini K.H. Imam Zarkasyi bertindak sebagai Direktur KMI atau guru yang mengajar di depan kelas, sementara di dalam sistem pesantren berperan sebagai kiai yang selalu memberikan wejangan-wejangan moral serta pengarahan-pengarahan tentang filsafat hidup dan wawasan keislaman yang lebih luas.

Pondok Modern Gontor termasuk pesantren yang berani melakukan inovasi, di antaranya dengan tidak mengajarkan kitab kuning dengan metode wetonan, bandongan ataupun sorogan, melainkan dengan metode fath al kutub. Pondok Modern Gontor juga lebih memilih kitab Bidāyat al-Mujtahid untuk pengajaran fiqh pada kelas tinggi, ketika pondok pesantren lain lebih memilih kitab Fath al-Qarīb dan Fath al-Mu'in, sebagaimana dikutip Nasrullah dari Martin van Bruinessen, hanya dua pondok pesantren saja yang "berani" mengajarkan kitab Bidāyat al-Mujtahid.

Pondok Modern Gontor memilih metode tersendiri dalam mengajarkan tentang Islam, memahamkan tentang agama kepada para santrinya. Demikian juga dalam pengajaran Bahasa Arab dan Bahasa Inggris, misalnya, Pondok Modern Gontor lebih mendahulukan bahan daripada alat, mendahulukan contoh daripada kaidah/teori. Pelajaran $\mathrm{Nahw} w$, Șarf, at au grammar baru diajarkan setelah murid-murid menguasai sejumlah kosa kata secara produktif. Karenanya pula, penyampaian pelajaran 'ibādah, 'aqīdah, tārỉkh Islam, dan sebagainya pada awalnya diajarkan dalam Bahasa Indonesia, baru setelah murid sedikit menguasai Bahasa Arab, materi-materi itu disampaikan dalam Bahasa Arab. 


\section{E. Simpulan}

Pondok Modern Gontor yang secara sadar telah mengintegrasikan sistem pendidikan pesantren dan madrasah dalam pelaksanaan pendidikannya. Kedua sistem yang dipadukan itu menjadi hal penting yang mengindikasikan bahwa Pondok Modern Gontor tidak terjebak pada mindset dualisme-dikotomi pendidikan yang selama ini membuat sulit para pengelola lembaga pendidikan Islam untuk maju dan berkembang.

\section{Daftar Pustaka}

Abdullah, Amin. 1995. Falsafah Kalam di Era Postmodernisme. Yogyakarta: Pustaka Pelajar.

Ali, Mukti. 1987. Beberapa persoalan Agama Dewasa Ini. Jakarta: Rajawali 1998. Alam Fikiran Islam Modern di India dan Pakistan.

Bandung: Mizan.

Anis, Ibrahim et al. 1972. Al-Mu'jam al-Wasith. Kairo: Darul Ma'arif.

Azizy, A. Qodri A. 2002. "Memberdayakan Pesantren dan Madrasah" dalam Ismail SM (Ed.), Dinamika Pesantren dan Madrasah. Yogyakarta: Pustaka Pelajar.

Azra, Azyumardi. 1998. Esei-esei Intelektual Muslim dan Pendidikan Islam, Jakarta: Logos Wacana Ilmu.

1998. Pendidikan Islam Tradisi dan Modernisasi Menuju Millenium Baru. Jakarta: Logos Wacana Ilmu.

Bawani, Imam. 1993. Tradisionalisme dalam Pendidikan Islam. Surabaya: AlIkhlas.

Daya, Burhanuddin. 1990. Gerakan Pembaharuan Pemikiran Islam, Kasus Sumatera Thawalib. Yogyakarta: Tiara Wacana.

Djaelani, A.Q. 1983. Sistem Pendidikan Pondok Pesantren. Bogor: Badriyah Dhofier, Zamakhsyari. 1989. Tradisi Pesantren Studi tentang Pandangan Hidup Kyai. Jakarta: LP3ES.

Feisal, Jusuf Amir. 1995. Reorientasi Pendidikan Islam. Jakarta: Gema Insani Press.

Hakim, Luqman (Ed.). 2001. Pola Pembelajaran di Pesantren. Jakarta: Proyek Peningkatan Pondok Pesantren Depag RI.

Hasan, M. Nashihin. 1988. "Karakter dan Fungsi Pesantren”, dalam Manfred Oepen dan Wolfgang Karcher, Dinamika Pesantren: Dampak Pesantren dalam Pendidikan dan Pengembangan Masyarakat. Jakarta: P3M. 
Hasbullah. 2002. Sejarah Pendidikan Islam di Indonesia Lintasan Sejarah Pertumbuhan dan Perkembangan. Jakarta: Ciputat Press.

Hasyim, HM. Yusuf. 1988. "Peranan dan Potensi Pesantren dalam Pembangunan" dalam Manfred Oepen dan Wolfgang Karcher, Dinamika Pesantren: Dampak Pesantren dalam Pendidikan dan Pengembangan Masyarakat. Jakarta: P3M.

Khozin. 2001. Jejak-Jejak Pendidikan Islam di Indonesia. Malang: UMM Press Maksum. 1999. Madrasah Sejarah dan Perkembangan. Jakarta: Logos Wacana Ilmu.

Mastuhu. 1994. Dinamika Sistem Pendidikan Pesantren: Suatu Kajian tentang Unsur dan Nilai Sistem Pendidikan Pesantren. Jakarta: INIS.

Nakosteen, Mehdi. 2003. History of Islamic Origins of Western Education A.D. 800-1350; with an Introduction to Medieval Muslim Education, (terj.) Joko S. Kahar \& Supriyanto Abdullah. Surabaya: Risalah Gusti. Nata, Abudin. 2000. Pemikiran Para Tokoh Pendidikan Islam. Jakarta: Raja Grafindo Persada.

Noer, Deliar. 1982. Gerakan Modern Islam di Indonesia 1900-1942. Jakarta: LP3ES Yunus, H. Mahmud. 1995. Sejarah Pendidikan Islam di Indoensia. Jakarta: Mutiara Sumber Widya.

Penyusun. T.T. AD dan ART Badan Wakaf Pondok Modern Gontor. Gontor: Darussalam Press.

Rahardjo (Ed.), M. Dawam. 1995. Pesantren dan Pembaharuan. Jakarta: LP3ES. Rahman, Fazlur. 2000. Islam and Modernity, Transformation of an Intellectual Tradition, (terj.) Ahsin Mohammad. Bandung: Pustaka.

Rais, M. Amien. 1989. Cakrawala Islam: antara Cita dan Fakta. Bandung: Mizan Syalabi, Ahmad. 1987. Al-Tarbiyah al-Islāmiyah: Nudzumuhā, Falsafatuhā, Tarikhuhā. Cairo: Maktabah al-Nahdah al-Masriyah.

Tim Penyusun. 1996. Biografi K.H. Imam Zarkasyi: Dari Gontor Merintis Pesantren Modern. Jakarta: Gontor Press.

Wahjoetomo. 1997. Perguruan Tinggi Pesantren Pendidikan Alternatif Masa Depan. Jakarta: Gema Insani Press.

Wahid, Abdurrahman. 2001. Menggerakkan Tradisi: Esai-Esai Pesantren. Yogyakarta: LKiS.

Wirosardjono, Soetjipto. 1988. "Pesantren dan Peranan Islam di Indonesia", dalam Manfred Oepen dan Wolfgang Karcher, Dinamika Pesantren: Dampak Pesantren dalam Pendidikan dan Pengembangan Masyarakat. Jakarta: P3M. 
Wiryosukarto, Amir Hamzah. 1996. Biografi K.H. Imam Zarkasyi. Gontor: Gontor Press.

Yunus, Mahmud. 1995. Sejarah Pendidikan Islam di Indonesia. Jakarta: Mutiara Sumber Widya.

Yasmadi. 2002. Modernisasi Pesantren: Kritik Nurcholish Madjid terhadap Pendidikan Islam Tradisional. Jakarta: Ciputat Press.

Ziemek, Manfred. 1986. Pesantren dalam Perubahan Sosial, (terj.) Butche B. Soendjojo. Jakarta: P3M.

Zuhairini et al. 1997. Sejarah Pendidikan Islam. Jakarta: Bumi Aksara. 